\title{
Pengaruh Model Think Pair Share Dipadu Media Gambar Seri terhadap Kemampuan Bercerita Siswa Kelas IV
}

\author{
Amalia Rizkina $^{1}$, Imam Suyitno $^{2}$, Munzil $^{3}$ \\ ${ }^{1}$ Pendidikan Dasar-Universitas Negeri Malang \\ ${ }^{2}$ Pendidikan Bahasa Indonesia-Universitas Negeri Malang \\ ${ }^{3}$ Pendidikan Kimia-Universitas Negeri Malang
}

\begin{tabular}{l} 
INFO ARTIKEL \\
\hline Riwayat Artikel: \\
Diterima: $15-11-2018$ \\
Disetujui: $20-02-2019$ \\
\hline
\end{tabular}

Kata kunci:

think pair share; series picture media; storytelling ability; think pair share; media gambar seri; kemampuan bercerita

\author{
Alamat Korespondensi: \\ Amalia Rizkina \\ Pendidikan Dasar \\ Universitas Negeri Malang \\ Jalan Semarang 5 Malang \\ E-mail: amalia.rizkina17@ gmail.com
}

\section{ABSTRAK}

Abstract: This research aims to determine the effectof think pair share model's combined whit series picture to telling story ability at fourth grade student in Bunulrejo 01 Elementary School. This research is a experimental research with Post Test Only Design. Research subject includes 63 fourth grade student in Bunulrejo 01 Elementary School. The sampling technique israndom sampling technique. The series picture class is fourth grade students of IV-A. The think pair share model's class is fourth grade students of IV B. The think pair share model's combined whit series picture class is IV C. The data obtained were analyzed by using one-ways ANAVA. The results of the research is there is a difference of think pair share model's combined whit series picture to telling story ability at fourth grade student.

\begin{abstract}
Abstrak: Tujuan penelitian ini untuk mengetahui pengaruh model think pair share dipadu gambar seri pada kemampuan bercerita siswa kelas IV. Jenis penelitianini adalah eksperimen dengan menggunakan Post Test Only Desain. Sampel dalam penelitian ini adalah seluruh siswa kelas IV SDN Bunulrejo 01 yang berjumlah 63 siswa. Teknik pengambilan sampel dalam penelitian ini menggunakan teknik acak. Kelas IV-A dibelajarkan dengan menggunakan media gambar seri. Kelas IV-B dibelajarkan dengan menggunakan model pembelajaran think pair share. Kelas IV-C dibelajarkan dengan menggunakan model pembelajaran think pair share dipadu dengan media gambar. Data dalam penelitian ini dianalisis dengan menggunakan one way ANAVA. Hasil penelitian adalah ada perbedaan model pembelajaran think pair share dipadu dengan media gambar seri terhadap kemampuan bercerita siswa kelas IV.
\end{abstract}

Suatu pembelajaran akan tercipta dengan adanya interaksi antara guru dan siswa. Guru menjadi fasilitator pembelajaran. Sudirman (2016), menyatakan guru harus dapat mengarahkan siswa menggunakan metode secara tepat, mendengarkan, bertanya dan memberikan tanggapan, sehingga terjadi dialog yang menjadikan pembelajaran yang interaktif. Sejalan dengan hal tersebut syaiful (Sumantri, 2015), menerangkan pembelajaran ialah kegiatan komunikasi dua arah, guru sebagai pengajar dan peserta didik melakukan kegiatan belajar. Berdasarkan pendapat tersebut dapat dikatakan, proses pembelajaran pada dasarnya sebuah jalinan komunikasi antar guru dan peserta didik untuk menciptakan suasana interaktif dan komunikatif dalam situasi belajar. Kurikulum yang diterapkan sekarang adalah kurikulum 2013 yang memberikan kesempatan kepada peserta didik untuk lebih berperan banyak dalam proses pembelajaran. Kurikulum 2013 menerapkan sistem tematik yang dihubungkan antara muatan pelajaran yang satu dengan muatan pelajaran yang lainnya. Setiap tema menjelaskan pembelajaran sesuai muatan tertentu yang saling berkaitan sehingga dalam pembelajaran peserta didik dapat berpikir lebih luas. Kurniawan (2015) menyatakan satu tema disampaikan dalam berbagai mata pelajaran, yang disebut dengan tematik, yaitu pembelajaran yang seluruh mata pelajarannya disatukan dalam sebuah tema. Melalui sistem tematik ini, siswa tidak dibatasi oleh batasan pelajaran dalam merangsang dan mengembangkan sikap, pengetahuan dan keterampilan.

Pencapaian kompetensi dalam pembelajaran tematik salah satunya menitik beratan pada tuntutan penguasaan aspek keterampilan. Keterampilan dalam pembelajaran dapat diukur melalui kemampuan bercerita. Di sekolah dasar kemampuan bercerita yang dimiliki siswa sering kali tidak dinilai secara mendetail. Jadi, banyak aspek bercerita terlewatkan sehingga tidak mencerminkan sejauh mana keterampilan siswa untuk bercerita. Oleh karena itu pembelajaran harus dikembangkan dengan alternatif yang dapat digunakan yaitu menciptakan kegiatan belajar mengajar yang dikemas sedemikian rupa agar dapat memfasilitasi siswa mengembangkan kemampuaannya. Salah satunya adalah menggunakan model-model pembelajaran. Ada 
banyak model yang dapat digunakan oleh guru. Pada pembahasan ini salah satunya guru menggunakan model pembelajaran koopertif tipe think pair and share. Wulandari (2016), menyatakan model pembelajaran think pair share memiliki unsur dasar pembeda pembelajaran kooperatif dengan pembelajaran kelompok tradisional.

Pembelajaran kooperatif model think pair share proses pembelajaran berkelompok digunakan agar mencapai tujuan pembelajaran. Irawan (2018), menyatakan tujuan model think pair share yaitu menekankan kerja sama agar siswa dapat bertukar pikiran dalam proses pembalajaran yang berbasis kurikulum 2013. Sependapat dengan hal itu Ayuningtyas (2015); Lestari (2014), menyatakan model pembelajatan think pair share sebagai model pembelajaran khusus didesain mengutamakan kerja sama. Sejalan dengan pendapat tersebut suhartini (2015), mengungkapkan dalam pelaksanaan model think pair share siswa berperan banyak di kelompok nya memecahkan suatu permasalahan. Ramadhani (2017), sependapat bahwa kemampuan siswa secara individu dan kerja sama secara berpasangan menimbulkan dugaan positif mengenai yang mampu dilakukan siswa untuk ketercapaian hasil belajar. Wulandari (2017), juga sependapat model think pair share memberi jangka waktu yang menunut siswa agar bekerja secara individu, berdisuksi untuk saling bertukar pikiran, sehingga siswa model ini mendorong siswa bekerja sama berpasangan mencapai tujuan pembelajaran. Sehingga dengan model think pair share terjadi pembicaraan, percakapan, perundingan dan tanya jawab antar siswa yang menjadikan pembelajaran yang interaktif.

Model think pair and share merupakan model pembelajaran yang memberi kesempatan kepada masing-masing siswa untuk mengembangkan pengetahuan dan kemampuannya. Asdar (2016), menyatakan bahwa model think pair share (pada setiap tahap terus mengalami peningkatan aktivitas siswa pada tahapan think aktivitas meningkat ketahapan share terus meningkat ketahapan pair dan siswa juga mengalami pembelajaran bermakna. Sejalan dengan pendapat tersebut kothiyal (2013); Mariani (2017); Kahel \& Hamdan (2017), berpendapat siswa dapat berpatisipasi secara langsung di dalam pembelajaran dengan pengetahuan awal yang sudah mereka miliki. Azila (2010), menguatkan bahwa model think pair share dalam pelaksanaannya mengarahkan siswa harus berpikir serta menyelesaikan masalah secara tepat dikarenakan siswa dilatih untuk membangun pengetahuannya sendiri, menentukan tindakan yang harus dilakukan, membangun serta memperoleh pengalaman berharga. Sehingga model pembelajaran think pair share mempunyai tata cara untuk digunakan dengan cara terperinci untuk memberi siswa waktu luang berpikir sendiri, berpasangan serta berbagi untuk mengembangkan kemampuannya.

Pada pelaksanaannya model think pair share memiliki kelemahan. Kelemahan model think pair share terletak pada tahapan think siswa merasa kesulitan mendeskripsikan unsur-unsur yang ada pada cerita melalui teks saja sehingga model pembelajaran kooperatif jenis think pair share dapat dipadukan dengan media gambar seri. Media gambar seri merupakan alat yang memudahkan siswa untuk memahami cerita karena melalui gambar seri siswa dapat melihat rangkaian cerita secara kongkrit. Tana (2016) mengungkapkan media gambar seri dapat dimanfaatkan siswa untuk mengungkapkan gagasan atau ide dalam bentuk lisan. Sehingga dibantu dengan media gambar seri diyakini dapat membantu memaksimalkan hasil kemampuan bercerita. Pemecahan masalah tersebut yaitu dengan menggunakan model pembelajaran think pair share yang dipadu media gambar seri agar siswa berperan lebih serta dapat mengembangkan gagasan gagasannya dengan baik dan runtut. Berdasarkan latar belakang yang telah diuraikan di atas.

\section{METODE}

Penelitian ini menggunakan jenis penelitian eksperimen semu. Populasi pada penelitian adalah keseluruhan siswa kelas IV SDN Bungulrejo 01 tahun pelajaran 2017/2018 yang berjumlah 63 orang. Teknik pengambilan sampel dalam penelitian ini menggunakan teknik acak. Hal ini didasarkan karena di SDN Bunulrejo 01 terdapat tiga kelas yaitu IVA, IVB dan IVC yang memiliki kemampuan yang sama. Oleh karena itu, ketiga kelas tersebut masing-masing mendapat perlakuan. Kelas IV-A dibelajarkan dengan menggunakan media gambar seri. Kelas IV-B dibelajarkan melalui penggunaan model think pair share. Kelas IV-C dibelajarkan melalui penggunaan model think pair share dipadu dengan media gambar seri. Instrumen penelitian ini menggunakan tes kemampuan bercerita. Sebelum digunakan dalam penelitian, dilakukan validasi ahli. Data dalam penelitian ini kemudian dianalisis dengan menggunakan one way ANAVA.

\section{HASIL}

Sebelumnya akan dibahas keterlaksanaan pembelajaran dilaksanakan oleh guru di ketiga kelas tersebut. Berdasarkan hasil observasi keterlaksanaan pembelajaran dilaksakan guru di ketiga kelas diperoleh data sebagaimana tabel 1.

Tabel 1. Penilaian Kemampuan Guru Dalam Mengelola Pembelajaran

\begin{tabular}{cccc}
\hline \multirow{2}{*}{ Pertemuan Ke- } & \multicolumn{3}{c}{ Penilaian Guru dalam Mengelola Pembelajaran } \\
\cline { 2 - 4 } & Think pair share dipadu gambar seri & Think pair share & Media \\
\hline 1 & 92 & 90 & 94 \\
2 & 90 & 93 & 92 \\
3 & 94 & 88 & 90 \\
4 & 90 & 90 & 90 \\
5 & 96 & 95 & 94 \\
\hline Rata-rata & 92 & 92 & 92 \\
\hline
\end{tabular}


Pada kelas dengan model think pair share dipadu media gambar seri rata-rata mengalami peningkatan. Guru dalam mengelola pembelajaran pada setiap pertemuannya sangat baik. Pada kelas dengan model think pair share rata-rata mengalami peningkatan. Guru dalam mengelola pembelajaran pada setiap pertemuannya sangat baik. Pada kelas menggunakan gambar seri rata-rata mengalami peningkatan. Guru dalam mengelola pembelajaran pada setiap pertemuannya sangat baik. Guru bertindak sebagai fasilitator mengarahkan dan memberi peluang sebanyak-banyaknya pada siswa untuk mengembangkan pengetahuan serta kemampuan, dan melatih siswa untuk mengambil tanggung jawab sendiri untuk memnuhi tujuan belajarnya sehingga guru sangat baik dalam melaksanakan pembelajaran. Selain dilakukan observasi terhadap keterlaksaan pembelajaran yang dilaksanakan guru, juga dilakukan pengamatan terhadap keterlaksaan pembelajaran yang dikerjakan oleh siswa.

Tabel 2. Penilaian Aktivitas Siswa Dalam Mengikuti Pembelajaran

\begin{tabular}{cccc}
\hline \multirow{2}{*}{ Pertemuan Ke- } & \multicolumn{3}{c}{ Penilaian Aktivitas Siswa mengikuti pembelajaran } \\
\cline { 2 - 5 } & Think Pair Share dipadu Gambar Seri & Think Pair Share & Media \\
\hline 1 & 92 & 90 & 94 \\
\hline 2 & 90 & 93 & 92 \\
\hline 3 & 94 & 88 & 90 \\
\hline 4 & 90 & 90 & 90 \\
\hline 5 & 96 & 95 & 94 \\
\hline 6 & 95 & 94 & 94 \\
\hline Rata-rata & 92 & 92 & 92 \\
\hline
\end{tabular}

Pada kelas dengan model think pair share dipadu media gambar seri rata-rata mengalami peningkatan. Aktivitas siswa dalam mengikuti pembelajaran pada setiap pertemuannya sangat baik. Pada kelas dengan model think pair share rata-rata mengalami kenaikan. Kegitatan siswa dalam mengikuti pembelajaran pada setiap pertemuannya sangat baik. Pada kelas menggunakan gambar seri rata-rata mengalami peningkatan. Aktivitas siswa dalam mengikuti pembelajaran pada setiap pertemuannya sangat baik. Siswa dalam proses pembelajaran memperoleh pengetahuan dan kemampuannya sendiri yaitu siswa mengalami, mempelajari, memahami dan mengomunikasikan hasil pemikirannya ditemukan oleh siswa sendiri. Sehingga siswa mencapai tujuan belajarnya dan aktivitas siswa mengikuti pembelajaran berjalan dengan sangat baik.

Tabel 3. Nilai Post Test

\begin{tabular}{lc}
\hline \multicolumn{1}{c}{ Perlakuan } & Rata-rata \\
\hline Think Pair Share & 84 \\
\hline Gambar Seri & 88 \\
\hline Think Pair Share dipadu Media Gambar Seri & 92 \\
\hline
\end{tabular}

Berdasarkan hasil uji normalitas kemampuan bercerita siswa dengan menggunakan Kolmogorov Smirnov diketahui data ketiga kelas tersebut berdistribusi normal. Hal ini ditunjukkan pada kelas dengan model think pair share diperoleh signifikansi 0,129 dan nilai signifikansi tersebut lebih besar dari 0.05. Pada kelas yang dibelajarkan dengan menggunakan media gambar seri diperoleh nilai signifikansi 0,200 dan nilai signifikansi tersebut lebih besar dari 0.05. Selanjutnya kelas dengan model think pair sharedipadu dengan media gambar seri diperoleh nilai signifikansi 0,200 dan nilai signifikansi tersebut lebih besar dari 0.05. Selain uji normalitas juga dilakukan uji homogenitas terhadap data hasil kemampuan bercerita siswa dengan menggunakan Levene Statistic. Berdasarkan hasil uji homogenitas diperoleh bahwa kemampuan bercerita siswa yang akan dianalisis memiliki varian yang sama. Hal ini ditunjukkan dengan nilai signifikansi yang diperoleh yaitu sebesar 0.077 . Nilai tersebut lebih besar dari 0.05, sehingga dapat disimpulkan bahwa data pada ketiga kelas tersebut memiliki varian yang sama. Selanjutnya, dilakukan uji hipotesis dengan menggunakan uji Anava satu jalur (one way anava)

Tabel 4. Hasil Uji Hipotesis Kemampuan Bercerita Siswa

\begin{tabular}{|l|r|r|r|r|r|}
\hline & Sum of Squares & Df & Mean Square & F & Sig. \\
\hline Between Groups & 50.508 & 2 & 25.254 & 4.003 & .023 \\
Within Groups & 378.571 & 60 & 6.310 & & \\
Total & 429.079 & 62 & & & \\
\hline
\end{tabular}

Tabel 4 menunjukkan bahwa berdasarkan hasil analisis dengan menggunakan uji one way ANOVA menunjukkan bahwa ada pengaruh model pembelajaran think pair share dipadu dengan media gambar seri terhadap kemampuan bercerita siswa. Hal ini ditunjukkan dari hasil signifikansi yang diperoleh yaitu sebesar 0,023. Hasil signifikansi yang diperoleh lebih kecil dari 0,05, sehingga dapat disimpulkan bahwa ada pengaruh model pembelajaran think pair share dipadu dengan media gambar seri. 


\section{PEMBAHASAN}

Pembelajaran pada kelas dibelajarkan dengan model think pair share, kelas yang dibelajarkan menggunakan media gambar seri dan kelas yang dibelajarkan dengan model think pair share dipadu media gambar seri sudah sesuai dengan apa yang termuat di RPP. Kelas yang dibelajarkan menerapkan model think pair share dalam pembelajaran perlu pembiasaan namun tetap berjalan dengan lancar. Pada tahap think (berpikir) secara individu siswa mencari unsur-unsur cerita dan berdasarkan teks cerita dan menuliskannya pada kolom siswa sudah mampu menemukan judul, beberapa tokoh, beberapa sifat tokoh, beberapa tempat namun masih kesulitan menentukan awal cerita akhir cerita dan pesan moral sehingga jawaban belum rinci. Selanjutnya, pada tahap pair (berpasangan) siswa saling mengutarakan hasil temuannya maka jawaban siswa sudah mulai lengkap menuliskan judul, tokoh, sifat tokoh, tempat, sudah dapat menentukan awal cerita dan akhir cerita namun belum dapat mengungkap secara mendalam pesan moral yang terdapat pada cerita.

Pada tahap share (berbagi) masing-masing kelompok diberi kesempatan untuk membagi pengetahuannya yang diperoleh ketika berpikir sendiri dan hasil permikiran bersama pasangan siswa dapat mengecek kebenaran atas pemikiran sendiri dan bersama pasangan pada tahapan share (berbagi) temuan unsur-unsur judul, tokoh, sifat tokoh, tempat, awal cerita dan akhir cerita sudah disampaikan secara rinci dan saling menambahkan jawaban dan yang belum rinci dapat memikirkan kembali dan memperoleh pengetahuan yang benar dan saat menyampaikan pesan moral siswa saling menambahkan sehingga lengkaplah pesan moral yang ingin ditanamkan pada siswa. Pada setiap pertemuannya semakin banyak siswa yang mengacungkan tangan agar diberikan kesempatan untuk berbicara sharing kepada teman sekelas. Sehingga dapat diketahui tahap think tahap pair tahap share dapat menstimulus cerita kapada siswa dan melatih kemampuan siswa berbicara dan akan mengasah kemampuan bercerita siswa.

Pada kelas yang dibelajarkan dengan media gambar seri respon siswa terhadap media memacu ada nya rasa senang untuk belajar, media gambar seri membantu siswa memahami cerita dongeng secara runtut karena tergambar secara kongkrit alur cerita, tokoh, latar, suasana, adegan demi adegan didalam media gambar seri. Penggunaan media gambar seri dengan cara siswa diberi kesempatan untuk menyusun gambar secara runtut. Semua siswa sangat ingin menyusun gambar secara tidak langsung siswa memahami tahu dengan jelas cerita dongeng agar ia bisa menyusun secara tepat yang kebenaran keruntutan nya akan dinilai oleh semua teman nya dikelas sehingga menggunakan media gambar seri dapat membantu siswa mengetahui isi cerita dongeng sehingga dapat mengasah kemampuan siswa untuk bercerita.

Pada kelas dibelajarkan dengan model think pair share dipadu media gambar seri keterlaksanaan pada tahap think (berpikir) secara individu siswa mencari unsur-unsur cerita berdasarkan teks cerita dan melihat secara kongkrit cerita pada gambar seri menyebabkan siswa mampu menuliskan pada kolom judul, tokoh, sifat tokoh, tempat, menentukan awal cerita akhir cerita hanya saja pesan moral pada cerita belum dapat diungkapkan secara mendalam. Selanjutnya pada tahap pair (berpasangan) siswa saling mengutarakan hasil temuaannya menggunakan media gambar seri sehingga penyampaian dan tanggapan dapat diungkapkan dan dipahami secara baik oleh kedua pasangan maka jawaban siswa semakin yakin dan mantap temuan judul, tokoh, sifat tokoh, tempat, awal cerita dan akhir dan lebih banyak kesempatan mengungkapkan pesan moral yang terdapat pada cerita. Kemudian dilanjutkan pada tahap share (berbagi) berjalan dengan lancar masing-masing kelompok membagi pengetahuannya yang diperoleh ketika berpikir sendiri dan hasil permikiran bersama pasangan serta dapat mengecek kebenaran atas pemikiran sendiri dan bersama pasangan.

Pada tahapan share (berbagi) temuan unsur-unsur judul, tokoh, sifat tokoh, tempat, awal cerita dan akhir cerita disampaikan secara rinci, tepat dan mantap saat menyampaikan pesan moral lebih banyak siswa yang mengacungkan tangan untuk berbicara sharing mengungkapkan pendapatnya sehingga lengkaplah pesan moral yang ingin ditanamkan pada siswa. Kemudian pada tahap selanjutnya siswa diberikan kesempatan menggunakan media gambar seri dengan cara menyusun berurutan untuk membantu siswa memahami cerita yang akan diceritakan kembali. Guru memberikan kesempatan kepada seluruh siswa untuk mengamati penyusunan gambar seri kemudian memberikan pendapat terhadap ketepatan urutan gambar seri. Penggunaan media gambar seri yang diberikan kepada siswa juga membuat siswa sangat antusias memahami cerita agar dapat dengan runtut menyusun gambar. Model think pair share dipadu media gambar seri pada pembelajaran saling melengkapi memaksimalakan proses pembelajaran yang mengolah kemampuan bercerita siswa sehingga membuat siswa memiliki kemampuan lancar dan pasih bercerita.

Paparan hasil di atas senada dengan hasil beberapa penelitian sebelumnya, yaitu di antaranya (1) Fatimah (2015), dengan penelitian implementasi think pair share dalam pembelajaran bercerita. Menunjukkan adanya hasil siswa sebagai penerima pembelajaran think pair share kurang lebih dapat memecahkan hambatan pada terlaksanaan kegiatan bercerita; 2) Ngafifi (2014), hasil penelitian menyatakan penerapan model pembelajaran think pair share berbantu media mampu meningkatkan aktivitas belajar, perilaku siswa dilihat dari keefektifan hasil belajar dan meningkatkan hasil belajar ranah kognitif. 3) Surida (2016), pada hasil penelitannya menyatakan melalui media gambar seri dapat meningkatkan keterampilan berbicara dengan cara menceritakan media gambar seri dengan bahasa sendiri dengan lafat dan intonasi yang sesuai; 4) Sudarmiah (2009), pada hasil penelitiannya menyatakan keterampilan dengan menggunakan gambar seri dapat meningkatkan pembelajaran berbicara serta siswa, mengalami peralihan kehal lebih baik, terbantu dan tertarik pada kegiatan pembelajaran keterampilan berbicara; 5) Permana, Hilaliyah, \& Muzak (2016), pada hasil penelitiannya menyatakan perhitungan dan analisis data diperoleh adanya pengaruh media gambar seri pada kemampuan menulis narasi siswa SMP IT Darus-Sholihin Sawangan Depok; 6) Craw (2002), menyimpulkan hasil penelitiannya bahwa pada tahapan share siswa mendengarkan hasil kerja 
temannya akan membuat mereka mengoreksi dan merumuskan pemikiran mereka, menghargai pendapat orang lain, ketika kelompok berhasil akan meningkatkan rasa percaya diri dan menumbuhkan motivasi untuk bekerja sama. Berdasarkan berbagai jenis penelitian terdahulu dilakukan oleh beberapa peneliti, sehingga tepatlah dikatakan bahwa model think pair share dipadu dengan media gambar seri dapat memberikan pengaruh terhadap kemampuan bercerita siswa kelas IV.

\section{SIMPULAN}

Simpulan berdasarkan hasil penelitian ini dikemukakan bahwa pengaruh model pembelajaran think pair share dipadu media gambar seri terhadap kemampuan bercerita siswa. Hal tersebut terlihat dari hasil signifikansi yang diperoleh yaitu sebesar 0,023. Hasil signifikansi yang diperoleh lebih kecil dari 0,05. Sesuai dengan kesimpulan di atas, diberikan saran sebagai berikut. Bagi siswa dapat meningkatkan aktivitas siswa selama pembelajaran sehingga siswa dapat mengembangkan kemampuannya dalam aspek keterampilan. Bagi guru dapat menjadikan model dan media sebagai rujukkan untuk digunakan di dalam pembelajaran supaya mengetahui kemampuan siswa dalam bercerita.

\section{DAFTAR RUJUKAN}

Ayuningtyas, D. A. (2015). Esperimentasi Model Pembelajaran Kooperatif Tipe Think Pair Share ditinjau dari Kemandirian Belajar Siswa Kelas VIII SMP Negeri di Kota Yogyakarta. Jurnal Ilmiah Pendidikan Matematika, 3(2), 452-466. DOI: http://doi.org/10.25273/jipm.v3i2.514

Azlina, N. A. N. (2010). CETLs: Supporting Collaborative Activities Among Students and Teachers Through the Use of ThinkPair-Share Techniques. International Journal of Computer Science, 7(5), 18-29.

Crawford, M. (2002). Contextual Teaching and Learning: Strategies for counting Constructivist Classrooms. Connection, 11(9), $1-5$.

Fatimah, N. (2015). Implementasi Cooperative Learning Tipe Think-Pair-Share Dalam Pembelajaran Bercerita Di Sekolah Menengah Pertama. Jurnal Penelitian Humaniora, 16(2), 90-98. https://doi.org/10.23917/humaniora.v16i2.1862.

Hamdan, R. K. A. (2017). The Effect of Think - Pair - Share Strategy on the Achievement of Third Grade Student in Sciences in the Educational District of Irbid. Journal of Education and Practice, 8(9), 88-95.

Irawan, A. A., \& Kusumajanto, D. D. (2018). Meningkatkan Aktivitas dan Hasil Belajar Siswa dengan Menerapkan Pembelajaran Kooperatif Model Think Pair Share Berbasis Kurikulum 2013. Jurnal Pendidikan Bisnis \& Manajemen, 1(3), 199-2015.

Kothiyal, A. (2013). Effect of Think-Pair-Share in a Large CS1 Class: 83\% Sustained Engagement. Journal ICER, 13, 137-144. Kurniawan, H. (2015). Pembelajaran kreatif bahasa Indonesia (kurikulum 2013). Jakarta: Kencana.

Lestari, P. E. (2014). Menumbuhkan Keberaniaan Berpendapat melalui Model Pembelajaran Kooperatif Think Pair Share. Jurnal Madaniyah, (edisi VII), 191-2014.

Mariani, S. (2017). Think Pair Share Using Realistic Mathematics Education Approach in Geometry Learning Think Pair Share Using Realistic Mathematics Education Approach in Geometry Learning. Internasional Conference on Mathematics and Science Education (ICMScE), 1(20).

Ngafifi, M., \& Astuti, I. S. (2014). Penerapan Model Think Pair Share Berbantuan Media Untuk Meningkatkan Aktivitas, Sikap dan Hasil Belajar IPS. Harmoni Sosial: Jurnal Pendidikan IPS, 1(1), 57-70. https://doi.org/10.21831/hsjpi.v1i1.2428

Permana, A., Hilaliyah, H., \& Muzak, A. (2016). Pengaruh Penggunaan Media Gambar Berseri Terhadap Kemampuan Menulis Narasi Peserta Didik Sekolah Menengah Pertama (SMP). Dialektika: Jurnal Bahasa, Sastra dan Pendidikan Bahasa Dan Sastra Indonesia, 3(1), 87-99. DOI: https://doi.org/10.15408/dialektika.v3i1.4184

Ramadhani, P. S. (2017). Pengaruh Pendekatan Cooperative Learning (TPS) Think, Pair, Share Terhadap Hasil Belajar PKn di Sekolah Dasar. Jurnal Pendidikan Dasar dan Pembelajaran, 7(2), 124-134. DOI: http://doi.org/10.25273/pe.v7i2.1653

Sudarmiah, S. (2009). Upaya Peningkatan Pembelajaran Berbicara Dengan Model Pembelajaran Gambar Seri untuk Siswa Kelas VIII SMP Negeri 6 Semarang. Jurnal Media Penelitian Pendidikan, 3 (2). http://dx.doi.org/10.26877/mpp.v3i2.292.

Sudirman. (2016). Penerapan Model Pembelajaran Think Pair Share untuk Meningkatkan Hasil Belajar IPA Siswa. Jurnal Pendidikan Fisika, 4(1), 59—67. DOI: http://dx.doi.org/10.24127/jpf.v4i1.394

Suhartini. (2015). Peningkatan Keterampilan Menulis Naskah Drama Satu Babak Menggunakan Model Think Pair Share Berbantuan Alat Peraga Gambar Berseri. Satya Widya, 31(2). 83-89. https://doi.org/10.24246/j.sw.2015.v31.i2.p8389.

Sumantri, M. S. (2015). Stategi Pembelajaran Teori dan Praktik di Pendidikan Dasar. 2015. Jakarta: PT. Rajagrafindo Persada.

Surida. (2016). Peningkatan Pembelajaran Keterampilan Berbicara Melalui Media Gambar seri di Kelas III 17 Batang Anai Kabupaten Padang Pariaman. Jurnal Konseling dan Pendidikan, 4(2), 13-19.

Tana. (2016). Meningkatkan Keterampilan Berbicara Siswa Kelas I melalui Penggunaan Media Gambar Seri. Jurnal Pendidikan Indonesia, 2(1), $73-79$. 
261 Jurnal Pendidikan, Vol. 4, No. 2, Bln Februari, Thn 2019, Hal 256-261

Wulandari, S. W. (2016). Meningkatkan Kemampuan Komunikasi dan Motivasi Belajar Matematika Siswa Sekolah Dasar Melalui Pembelajaran Kooperatif Tipe Think-Pair-Share (TPS). Eduhumaniora: Jurnal Pendidikan Dasar, 7(2). http://dx.doi.org/10.17509/eh.v7i2.2710.

Wulandari, T., \& Safitri., M. N. (2017). Perbedaan Metode STAD dan TPS dalam Meningkatkan Kerja Sama dan Aktivitas Belajar Pada Pembelajaran IPS SMP. Jurnal Pendidikan IPS, 4(1), 80—90. https://doi.org/10.21831/hsjpi.v4i1.10493 